\title{
'They Can Never Write the Landscapes out of Their System'1 Engagements with the South African Landscape
}

\author{
JESSICA MURRAY \\ Centre for Culture and Languages in Africa, University of Johannesburg, South \\ Africa
}

\begin{abstract}
This article explores the ways in which the South African author Antjie Krog challenges imperial and patriarchal assumptions about bodies and landscapes in order to enable an embodied engagement with the South African landscape. Post-apartheid South Africa presents particular challenges to white identity and Krog's work recognises that a reconceptualised relationship between her body as a white South African woman and the South African landscape is a necessary part of coming to terms with her place in the new South Africa. The article will focus on Krog's 'Country of my Skull' (1998) and 'A Change of Tongue' (2003). Both these works deal with her narrators' struggle to feel part of South Africa after the atrocities of apartheid that were committed in the name of white South Africans. While sections of these texts have been fictionalised, they also include non-fictional accounts of South Africa's past, specifically through the inclusion of snippets of testimony from the Truth and Reconciliation Commission. I identify the challenges that Krog faces when she enters the over determined discursive field of landscape writing in general and of South African landscape writing in particular and theorise how her embrace of bodies, mutuality and fluidity opens up new possibilities for being a white woman in the landscape of postapartheid South Africa.
\end{abstract}

\section{Introduction}

This article will consider the ways in which the South African author Antjie Krog enters the over determined discursive field of landscape writing by means of a highly self-reflexive engagement with landscape in order to redefine the relationship with that landscape. She addresses issues of trauma, violence and identity by exploring the connections between the bodies of her characters and the landscapes they inhabit. While other forms of language seek to communicate by means of 'references to the world existing outside of language' (Abrams, 1999, p. 103), literature focuses on the signifiers themselves and, in doing so, literature has the capacity to make readers experience the world in new and alternative ways. The extent to which patriarchal ${ }^{2}$ assumptions are embedded in discourses and representations of landscape and women's bodies makes literature a particularly useful medium through which to consider alternatives to existing cultural encodings of the relationship between women's bodies and Africa. 
Krog writes from a spatial and temporal location of an entire nation struggling to deal with the impact of apartheid on individual and collective identities. While the South African Truth and Reconciliation Commission (TRC) made considerable strides in addressing these issues, it is important to remember that the TRC's work was circumscribed by the fact that it was set up as part of a compromise between South Africa's political groupings to enable the transition from apartheid rule to democracy. This meant that the TRC could only ever constitute a point of departure, albeit a crucial one, rather than a completed process. According to Jaffer and Cronjé (2004, p. 8) '[t]he vastness of the exercise .... unearthed a body of material that provided a solid foundation for understanding the past and beginning to deal with it' [emphasis added]. The messy ambiguities resulting from a compromise of this scale could not be dealt with comprehensively within the limited ambit of the TRC and Krog has taken up the challenge of dealing with these ambiguities in her writing. Literature provides the scope for the legalistic and necessarily constrained discourses of the TRC to be pushed into a sphere where more in-depth analysis is possible. As the rest of the article illustrates, the problems of land ownership and white belonging in the South African landscape remain contentious topics that tended to be elided in the TRC's focus on gross human rights violations.

In order to ward off terminological confusion, some clarification of my use of the concept of 'landscape' is necessary. Landscapes are aesthetic and cultural constructions that are 'created by people - through their experience and engagement with the world around them' (Bender, 1993, p. 1). Landscape is a broader concept than land in that it encompasses much more than the earth's surface. It is 'subjected to poetic and hermeneutic interpretation and [it is] a place where value and emotion coincide' (Morphy, 1993, p. 205). The most succinct definition of landscape comes from Denis Cosgrove (1984, p. 13) who states that landscape 'denotes the external world mediated through subjective human experience in a way that neither region nor area immediately suggest'. He goes on to explain that landscape is "not merely the world we see, it is a construction, a composition of that world'. Similarly, Simon Schama (1995, pp. 6-7) notes that ' $[t]$ here is an elaborate frame through which our adult eyes survey the landscape [...] Before it can ever be a repose for the senses, landscape is the work of the 
mind. Its scenery is built up as much from strata of memory as from layers of rock'.

While land is undoubtedly an emotionally evocative entity, that emotional engagement between person and place is not an integral part of the definition of land. Emotion is, in other words, connotatively rather than denotatively linked to the concept of land. A landscape is a phenomenon that a particular person perceives and experiences and it includes, but is not necessarily limited to, the surface of the land, what lies beneath and above the land, as well as the memories, dreams and imagination that are centred on that place. Any engagement with landscape must, however, bear in mind Gillian Rose's (1993, p. 89) caution that 'a landscape's meanings draw on the cultural codes of the society for which it was made' and that 'these codes are embedded in social power structures'. When a white South African woman considers her relationship with the landscape, she must thus consider the power relations that flow from both patriarchy and apartheid ${ }^{3}$.

This article goes on to argue that, for Krog's characters, the landscape forms a crucial layer of their identities. The conceptual clarification between land and landscape is significant because, even though the land has been appropriated by the racist and misogynist ${ }^{4}$ discourses of South African nationalism, Krog explores the intricate and meaningful relationships between individual protagonists and the landscapes they imaginatively inhabit. ${ }^{5}$ However, any attempt to work with and between these concepts of land and landscape must recognize Beningfield's (2006:6) caution that, while they 'exist in apparently conflicting forms - physical and imaginary, urban, rural and natural ... these forms have [always] been integrated and intertwined'. While the distinction provides a useful analytical tool, one should not lose sight of the extent to which these two terms shape each other.

\section{Theoretical challenges: female bodies and African landscapes}

In the attempt to write an embodied engagement with the African landscape, Krog is traversing tricky theoretical terrain. On the one hand there is the danger of perpetuating the tradition of Western landscape representation with its 'objectifying, self-effacing, colonizing (usually white, usually male) "gaze"' (Foster, 1998, p. 325) where writers 'experience the world as a kind of 
exhibition' and tend to inscribe 'their own subjectivity and perceptual models on all they see'. This tradition is well documented in, for example, Edward Said's Orientalism (1978), Sara Suleri's The Rhetoric of English India (1992) and Mary Louise Pratt's Imperial Eyes: Travel Writing and Transculturation (1992).

On the other hand, the assertion of a bodily connection with the landscape runs the risk of equating the female body with landscape. Gillian Rose's Feminism and Geography: The Limits of Geographical Knowledge (1993) provides a good overview and critique of this equation. The equation of women and land has a long tradition in African fiction. In Chinua Achebe's (1958) Things Fall Apart, for example, the main protagonist Okonkwo's friend Obierika makes the following comment: 'on an Eke market-day a little band of fugitives came into our town. Most of them were sons of our land whose mothers had been buried with us' (p. 97). In this sentence the men are described as sons of the land rather than women and their mothers' bodies literally merge with the land after death. In this Nigerian society women are defined in terms of their ability to bear sons and there is no doubt about the hierarchy of power: 'Okonkwo ruled his household with a heavy hand. His wives, especially the youngest, lived in perpetual fear of his fiery temper, and so did his little children' (p. 9$)^{6}$.

While the former mode of writing landscape disallows substantive engagement with the African landscape on its own terms, the latter plays into the tradition of justifying the exclusion of women from the realm of culture on the grounds of their supposedly inherent connection with nature. Kay Schaffer (1987, p. 52) sums up this problem as follows: 'The assumption that the masculine (man, Empire, Civilization) has an unquestioned God-given right to subdue or cultivate the feminine (woman, Earth, Nature) and appropriate the feminine to masculine domination is a constant construct of Western discourse'. Annette Kolodny addresses similar concerns in her The Lay of the Land: Metaphor as Experience and History in American Letters (1975) while Louise Bethlehem's Skin Tight: Apartheid Literary Culture and its Aftermath (2006) considers how the equation of the female body and the landscape manifests in South African literature ${ }^{7}$. I argue that Krog's works attempt to overcome these obstacles through a 'heterogeneously corporeal engagement with geographical space' (Foster, 1998, p. 326). While she insists on the 'sensing body' (p. 332) as the mode through which her characters encounter the landscape, these encounters are always 
'contradictory and fluid' (Viljoen, 2000, p. 3) and landscape becomes a 'shifting strategic source of identification without implying the adoption of ... a fixed, natural, or inherent identity' (Nash, 1994, p. 239).

Krog's texts seek to establish a kind of dialogue between the bodies of her characters and the landscapes they inhabit. This dialogue is both similar to, and different from the reciprocity between people and the land that Gerald Gaylard (2005, p. 253) alludes to in his argument that nationalist fiction 'is concerned to wrest the African landscape away from imperial "dark continent" otherings and maintain the animism of tradition which sees human and nature in harmony'. In his discussion of Australian Aboriginal ontologies, Richard Howitt (2000, p. 15) also points to the 'mutual entwinement that exists between people and country' and the extent to which 'one's identity and relationships in these cultural settings is not bound by the body but constructed in the interpenetration of bodies (human and non-human; past, present and future; here and not here) and places'. Although I am not suggesting that the Australian landscape and the Aboriginal culture are synonymous with the African landscape and the cultures of Krog's characters, Howitt's (2000, p. 15) argument about the inextricably intertwined nature of the bodies of people and the places they inhabit is similar to the ways in which Krog's characters engage with the landscape. Deborah Rose (1999, p. 180) also offers an explanation of the interaction between bodies and landscape in Aboriginal culture that is reminiscent of Krog's work: 'Subjects [...] are constructed both within and without; subjectivity is located within the site of the body, within the bodies of other people and other species, and within the world in trees, rockholes, on rock walls, and so on'.

This article will show that Krog works against the misogynist assumptions that often accompany traditional conceptions of 'nationalist fiction' and, while her engagement with the landscape can hardly be described as harmonious, she does reject the othering of the landscape in favour of an ongoing and dynamic interaction. Boehmer (1992, p. 6) has done considerable work on the gendered nature of nationalist discourse. She argues that '[f]igures of mothers of the nation are everywhere emblazoned but the presence of women in the nation is officially marginalised and generally ignored'. Christine Loflin (1998, p. 9) notes that, in 'Africa, the nation-space is often made inaccessible to women through African nationalism's use of the rhetoric of traditionalism in defending 
its nationalist goals'. In this rhetoric women's primary function tends to be as the 'bearer of nationalist sons' (Boehmer, 1992, p. 8).

Rather than dealing with the disempowering representational practices that have traditionally surrounded landscapes and women's bodies through rejection or denial, Krog banish these practices while retaining and redefining landscapes, women's bodies and the connections between them. ${ }^{8}$ Through a selfreflexive and meta-fictional engagement with discursive constructs that have long been employed to perpetuate women's disempowerment, Krog reclaims them and develops an embodied and geographically specific language that enables her female characters to testify to the trauma that has been imposed on their bodies and subjectivities.

\section{Landscape and white South African identity}

In A Change of Tongue, the return of Krog's narrator to the farm where she grew up forms an important part of her attempts to come to terms with both her individual and collective Afrikaner and South African identities in post apartheid South Africa. A Change of Tongue is a complex textual experiment in which Krog blends poetry, prose and extracts of witness testimony in a narrative that continuously unsettles the distinctions between the author and the narrator. While some sections of this fragmented, non-linear text are explicitly autobiographical, others are fictionalised to varying degrees. Krog attempts to conceptualise her place in South Africa with reference to the landscape: 'What effect does a landscape like this have on the psyche? What forms did freedom and democracy translate themselves into on these plains? Have they reached here?' (Krog, 2003, p. 27). Landscape can be 'a focus for the formation of identity' (Mitchell, 2002, p. 2) and it also constitutes a central element in the construction of one's national identity (Nash, 1994, p. 227-237; Bunn, 1994, p. 128) ${ }^{9}$. Krog's narrator is grappling with landscape's impact on identity formation at both these levels ${ }^{10}$. Viljoen (2000, p. 2) points out that '[s]pace has been prominent in traditional constructions of Afrikaner identity, as manifested in the importance attached to spatial elements (like place and landscape) in the Afrikaans literary tradition'. In this tradition, the connection between landscape and identity has some significant ideological nuances. In an essay about Breyten Breytenbach, J.M. Coetzee (1992, p. 377) explains that there are 
feelings of passionate intimacy with the South African landscape that, Afrikaners like to think, can be expressed only in Afrikaans, and therefore (here comes the sinister turn in the reasoning) can be experienced only by the Afrikaner. Closeness of fit between land and language is - so the reasoning goes - proof of the Afrikaner's natural ownership of the land.

Like Viljoen (2000, p. 3), I would argue that Krog's work illustrates a search for a new identity and that this includes 'reacquainting herself with and re-assessing the spaces, places and landscapes that previously constituted her identity as an Afrikaner and an Afrikaans writer'. Since this process involves a great deal of 'writing back' to the Afrikaans literary tradition, further scrutiny of Coetzee's analysis of this tradition will be useful at this point. In his White Writing: On the Culture of Letters in South Africa Coetzee (1988, p. 7) identifies the writer's need for interaction with the landscape: 'In the words he throws out to the landscape, in the echoes he listens for, he is seeking a dialogue with Africa, a reciprocity with Africa, that will allow him an identity better than that of visitor, stranger, transient'. The white writer's identity as a South African is thus dependent on a sense of belonging in the landscape.

\section{Land and ownership}

While the tradition of landscape writing in South Africa forms an important background to reading Krog's texts, the plaasroman [farm novel] as a specific strand within this tradition, is of particular significance. According to Coetzee (1988, p. 85), the South African farm is surrounded by the 'myth of natural right', which holds that 'the founding fathers pay for the farm in blood, sweat and tears, not in money: they hack it out of primeval bush, they defend it against barbarians, they leave their bones behind in its soil. Inherited ownership of the farm therefore becomes a sacred trust: to alienate the farm means to forsake the bones of the ancestors'.

In A Change of Tongue these sentiments are reflected in a conversation Krog's narrator's family has about the possibility of selling the farm. During the discussion the voice of her mother 'breaks through it all: "I will never sell this 
farm. My father and my grandfather will talk to me from their graves. I inherited it. I will not sell it, I will hand it over to my children, just as I received it from my father. This is your birth-ground"' (p. 189). Although her brother understands the practical necessity of selling the farm, his comments after their father dies reveal traces of the "myth of natural right': "'Do we really want to bury Pa in land that none of us farm any more? That we might sell soon? Would you like to be buried in somebody else's land?"' (2003, p. 360). Her brother answers her as follows: 'We all want to be buried on the farm, even if it is no longer ours. We are of it. That farm, that werf [farmyard], that's what made us. I want to be back there when I die. I will give myself back to it - by secret means if needs be. We have no face without that farm'.

Private ownership of land lies at the centre of both colonialism and patriarchy. The colonial enterprise sought to appropriate land for the White male colonizer while men's ownership of property, and the resultant economic power, enables the perpetuation of male dominance and female dependence that characterizes patriarchy. Land ownership was also at the heart of apartheid. The 'Natives Land Act' gave 90\% of land to white South Africans while the remaining 10\% went to other races. Although the 'Restitution of Land Rights Act 22' of 1994 has started to address the racial inequality in land redistribution, severe imbalances remain. The intertwined nature of private ownership of land, patriarchy, colonialism and apartheid helps one understand why white men cling to their land so tenaciously since the loss of land threatens to strip them of the privileges and power conferred by colonialism, apartheid and patriarchy. However, it is also significant that Krog notes how her mother resists losing their farm. Although white women were marginalized by the patriarchy of the apartheid regime, they were significant beneficiaries of the system's racist exploitation of black labor and its expropriation of land belonging to non-white races. Krog recognizes that white women's complicity in apartheid complicates any attempt at simple solidarity with her fellow South Africans. As a white Afrikaner woman, this renders her attempt to establish a new kind of relationship with the landscape all the more complicated.

\section{Silent and bodily engagements with landscape}


Coetzee (p. 167) explains the connection between landscape, language and identity as follows:

The questions that trouble white South African poets above all are, as we might expect, whether the land speaks a universal language, whether the African landscape can be articulated in a European language, whether the European can be at home in Africa. The most ominous answer is warned of in one of Leipoldt's poems: 'Hier praat die veld 'n onverstaanb're taal' (Here the veld speaks an incomprehensible language) ('Die Soutpan') [The Salt Pan] ${ }^{11}$.

In an attempt to counter this incomprehensibility, Coetzee argues that 'the project of landscape-writing in English comes to be dominated by a concern to make the landscape speak, to give a voice to the landscape, to interpret it' (p. 176). For the white South African writer, a silent landscape thus represents an unaccommodating and unresponsive space that cannot be a home. For this reason, 'what is felt with the greatest urgency by these poets is that silence, the silence of Africa, cannot be allowed to prevail: space presents itself, it must be filled (Coetzee, 1988, p. 177). When Krog's narrator is confronted with the vast and silent landscape of the rural Free State, the description reveals her appreciation of the beauty of the landscape rather than an urgent desire to appropriate that landscape through language:

I drive through the outstretched plains of the southern Free State [...] One is struck by the sense of an intentional vast emptiness ${ }^{12}$ in which far-off hilltops feature as slight draughts of breath. The landscape feels ancient and clear. Everything human feels accidental and threadbare - a residue to be simply scraped off one morning from the majestic monotony. Nothing ornamental is tolerated. Nothing that cannot endure so much sky (Krog, 2003, p. 27).

The reconceptualisation of silence as a way of speaking also allows Krog's narrator to interact with the landscape through her body. Rather than experiencing the 'vast emptiness' (p. 27) of the southern Free State as something 
alien, she regards this landscape as her home and, as she gets closer to Kroonstad, she realises that she has 'come to accept that there is earth that never leaves one's soul' (p. 34). While the narrator 'sits silently' (p. 50) on her grandfather's farm, her body's interaction with the landscape is described as follows:

In the middle a white stinkwood soars above the other trees and sprays out into the blue. She folds her body intimately around the pale, smooth trunk. Embraces its coolness, flattens her arms along the branches, heaves her head behind leaves. She becomes tree and bursts upwards to the sky (p. 49) ${ }^{13}$.

The mutuality of the embrace between the narrator and the landscape allows her to feel as if she becomes part of it. Krog's narrator regards human intervention in the landscape as something that feels superfluous and can 'simply be scraped off' (2003, p. 37). This is in marked contrast to Coetzee's (1988, p. 7) assertion that, ' $[\mathrm{t}]$ o the pastoral novel, landscape is humanized when inscribed by land and plough: in effect, the genre invokes a myth in which the earth becomes wife to the husband-man'. Despite the complete absence of human intervention, this landscape is already humanized for Krog's narrator. The hilltops are likened to breath and, rather than seeing people as making the land live, the landscape is alive in its own right with all human contributions being merely 'ornamental'.

Krog's need for a new kind of relationship with the land is necessitated by her location as a white South African woman. She needs to forge a connection with the landscape that moves beyond the disempowering myth that equates the woman with the land and sees both in terms of their roles as wife and mother while also addressing the overdetermined connection between white South Africans and the land that was institutionalised by apartheid. Her awareness of the urgency of this project is reflected in the following lines from Country of $M y$ Skull: "When the Truth Commission started last year, I realized instinctively: if you cut yourself off from the process, you will wake up in a foreign country - a country that you don't know and that you will never understand" (1998, p. 131). I follow Spearey $(2000$, p. 8$)$ in reading this text as one that 'foregrounds the interrelations between the topographical, the national and the corporeal' and examining the ways in which 'the borders of each, in narrative, psychological 
and substantive terms become the subject of enquiry and the object of reclamation [and] redefinition'. It becomes clear to Krog's narrator that such a redefinition of her relationship with the landscape is needed when she visits the family farm. For her, this is a return 'home' as she experiences it as crawling 'back into a womb' (p. 4) and she focuses on the comforts of a 'heavy-light eiderdown' and a 'hot-water bottle' that all contribute to a feeling of being '[o]vercome with the carelessness of [her] youth'. The extent to which things have changed does, however, become apparent when she wakes up to a night that 'is suddenly filled with menace' as her brothers pursue would-be cattle thieves. It is, according to Spearey (2000, p. 4), 'immediately evident that this landscape has altered and become disorienting and must be learned anew'.

\section{Marginalized figures: Focusing on the blind spots in representations of landscape}

Barnard (2007, p. 10) notes that, in 'the case of the South African pastoral, the chief occluded element is, of course, the labor of the black worker, whose inscriptions of and claim to the land constitute, as Coetzee has argued, the genre's embarrassing blind spot'. ${ }^{14}$ Krog works towards making visible the absent black man on the South African farm by, inter alia, describing how they were taken to Vlakplaas ${ }^{15}$ to be tortured and killed during apartheid. Japie Maponya, for example, 'was taken to Vlakplaas where he was assaulted by Eugene de Kock' (Krog, 1998, p. 64). In another section she relates how 'five black men in their blue Ford Escort turned on to the national road towards Lindley. Unbeknown to them, they swerved right in front of a deadly Vlakplaas contingent back from an operation' (p. 63). The Vlakplaas men opened fire, 'wounding four of them, one seriously' (p. 63).

In A Change of Tongue Krog's narrator meets Petrus, a black man who is present on a Free State farm as an owner of land. It becomes apparent that South Africa's transition to democracy has not automatically led to opportunities for black people to become farm owners. Krog's description of Petrus's acquisition of the farm reveals that he became the owner, almost by default, after white people were no longing willing to farm in such close proximity to a township. In this paragraph Krog also makes it clear that, despite the tendency of white writing to render the black man on the farm invisible, Petrus had been a foreman 
for 'nearly thirty years' (2003, p. 73) and that '[h]is fields were always impeccable, his harvests plentiful'. He was, however, not the owner of these farms as the narrator describes them as the 'magnificent Hugo farms':

When the New South Africa dawned and the farms near the town were being plundered on a daily basis, many farmers started to sell their land. The only man who was prepared to farm next to Maokeng township had been farming there for many years already. In 1997, Petrus Sithole and his long-time boss went to the Land Bank to borrow money for Petrus to buy the farm (p. 73).

Petrus thus continues to be dependent on his white employer when he needs to access capital and the racially perverted power relations between these men seem to remain intact despite the fact that Petrus becomes a land owner. Petrus recalls that, when he 'heard Baas Chris talk about land, [he] said yes immediately. And he helped me at the bank and he lent me tractors, his welding machine, planters and plough. He is a good man' (p. 73). Petrus's loyalty to the land, however, seems to go unrewarded as he faces the prospect of losing his newly acquired farm due to increasing debt. He also found that he 'struggled to fulfil his role as owner of a farm as well as foreman of the remaining Hugo farms. "In the first year I couldn't harvest, because I had to finish the Baas's own fields"' (p. 74).

If the presence of black men tends to be elided from farms, women are even more invisible. ${ }^{16}$ At a family reunion for the eightieth birthday of the narrator's Ouma Hannie, a discussion centres on the large numbers of white South African farmers who go to do contract work in America. When the narrator asks 'what is happening on their own farms in the meantime' (p. 22), she learns that "women carry on with the farming and the neighbours help where they can'. Even as one of her male family members admits that women are actively keeping the farms going in the absence of men, he makes a comment that reveals just how deeply ingrained his sense of female inferiority remains: 'And a new Department of Agriculture is like a new bride - only when she realizes her limitations does she become useful' (p. 22).

The reconceptualisation of the farm has taken on heightened importance in the light of the increased incidence of murders on farms and the heated, 
racially tinged public rhetoric accompanying it. Jennifer Wenzel (2000, p. 90) notes that, at 'the height of the farm murder crisis in late 1997, Afrikaner farmers had claimed to be in a "war situation" with, as Transvaal farmers' organization leader Willie Lewies claimed, "losses of life comparable to the Vietnam and Yugoslavian conflicts"'. While this is a considerable exaggeration, white farmers do consider themselves to be under siege. In Country of my Skull Krog's narrator describes an incident during her visit to the family farm. When she awakes to the commotion caused by cattle thieves, the scene is indeed reminiscent of a white family pulling together in a laager ${ }^{17}$ in the face of attack:

Andries's wife Bettie would now be standing on the roof of their house, from where she has a large part of the farm under surveillance with a night-vision scope. Bettie shouts the information down to the nine-year old Sumien at the Marnet, and she has to pass it on to her father in the bakkie [....] Sumien: 'Pa, where are you? Can you hear me?' Anxiety in her voice (Krog, 1998, p. 4).

In A Change of Tongue, Krog (2003, p. 27) returns to the issue of white farmers feeling under threat. The narrator relates the following story told to her by a friend Rina about how farmers were preparing for the first democratic election: 'Apart from stockpiling canned goods and ammunition, she informed me, some farmers from the western Free State had their wives and children sleep in black nightgowns and pyjamas: if the enemy attacked, they could flee unseen in the dark across the veld'. ${ }^{18}$ In this novel the threat experienced by white farmers is connected with the invasions of white owned farms in Zimbabwe. Joep Joubert, who is leasing the family farm Middenspruit, explains to Krog's narrator:

All of us here on the farms are in close contact with white farmers in Zimbabwe, and we study them and their options, and we learn! Maybe the biggest thing we learn from Zimbabwe is that the peaceful route does not work. And look at our government. No land reform plan. No real one (Krog, 2003, p. 70). 
Joep believes that, not only is the South African government not protecting white farmers, but they are actually planning to dispossess white farmers of their land through land invasions similar to those in Zimbabwe: 'While expertly using Mugabe and Nujoma to do the inciting for them, they [the South African government] swear in the name of holy capitalism that such things will never happen here...Yet they are carefully preparing the soil for it' (p. 70).

Krog's narrator attempts to understand Joep's anger and frustration about the possible loss of his land and, in the process, she explicitly links land to one's sense of identity:

The man sounds bitter, I think to myself. He is one of those Afrikaners whose forefathers, despite their Boer War bravery, lost their land during the Depression, and for whom land, over years and generations, has become a mythical ideal representing the ultimate of freedom, the ultimate of independence, the ultimate of being human. I have land, therefore I am. It is not for nothing that the old Afrikaans literature is filled with poetry and novels about the land and landscape (Krog, 2003, p. 75).

The narrator seems to be sympathetic to Joep's feelings of dispossession as she asks: 'Is ownership of land all that can name one? All that links one to this breathing earth?' (p. 76). The impact of land ownership, particularly of farms, on identity is a topic that Coetzee (1997, p. 22) also explores in his third person memoir Boyhood: Scenes from Provincial Life. Talking about the young protagonist, the narrator emphasises the importance of 'the two farms behind him, his mother's farm, his father's farm, and the stories of those farms' as it is ' $[\mathrm{t}] \mathrm{hrough}$ the farms he is rooted in the past; through the farms he has substance'. While Coetzee makes these points in the form of assertive statements, Krog phrases them as questions which go unanswered as they end chapter 14 of $A$ Change of Tongue.

In her attempt to theorize a new, non-racist model for Comparative Literature, Gayatri Chakravorty Spivak (2003, p. 26) suggests that we should let 'literature teach us that there are no certainties, that the process is open, and that it may be altogether more salutary that it is so'. Krog's acceptance of the 
uncertainty that is implied by unanswered questions echoes Spivak's celebration of irreducible alterity and infinite difference. Spivak insists that 'one cannot access another directly and with a guarantee' (p. 30) and it is by recognizing this impossibility that Comparative Literature is best able to 'resist mere appropriation by the dominant' (p.11). Similarly, Krog's narrator moves away from appropriating the landscape and seeking to own the land. Instead, she attempts to establish new ways of connecting to the landscape by exploring different modes of engagement and by accepting that this engagement will always be fluid and uncertain.

\section{Alternative connections with the South African landscape}

Krog's narrator's understanding that white ownership of the land in postapartheid South Africa cannot be sustained does not negate her need to feel connected to the land and this means that she has to renegotiate this connection. Once again, she turns to her bodily engagement with the land, which allows her to claim and keep her connection with the land in a way that has little to do with ownership. She describes going for a walk '[f]ar into the field, in the red grass, she sits down. She takes off her clothes. She lies on her back [....] She feels completely covered by mating termites, boring into the ground to establish new cities in the darkness' (p. 125). There is stark difference between this scene where Krog's narrator is naked in the landscape wishing to be 'part of the earth' and Jacobus Coetzee's attempts to claim the landscape in J.M. Coetzee's Dusklands. During Jacobus' '[s]ojourn in the land of the Great Namaqua' (1982, p. 66) there are repeated references to his nudity. Jacobus 'spat on the earth', 'kicked it' and 'clawed it' before he 'bored a sheath in the earth' (p. 95). This violent sexual attempt to penetrate the landscape ends in failure as he is 'reduced to a four-inch dangle and helpless urination'.

Krog's narrator's act of lying down in the landscape and allowing termites to cover her naked body result in pleasure and intoxicating joy. Rather than reading the narrator's actions as merely passive, however, I see it as enabling a reciprocal touch between her and the landscape. This is the kind of touch that allows an interactive connection with the landscape, which is something that the appropriative grabbing of Jacobus could never achieve. What Krog accomplishes, is to conceptualise a relationship with the land that relies on 
both the woman and the landscape being active and participating phenomena, thus distinguishing it from the disempowering trope that equates woman and landscape irrespective of the actions or characteristics of either.

Even as the changes in land distribution are taking place, she finds herself thinking '[t]hus it is to be part of the earth' (p. 125). The reconceptualisation of her relationship with the South African land makes her feel that 'she is on the edge of giddy discoveries - with nothing to betray or threaten her' (p. 125). Unlike Joep's sense of betrayal and her family's feeling of threat, she finds herself 'intoxicated by earth and grass' as she embraces the opportunity of engaging with the South African land in a way that is unmarred by ownership.

In the prose poem at the beginning of part two of the novel Krog articulates the bodily claim to the land by exploring the way in which landscape and body flow into one another:

Through the eyes of the giraffe you see a man. He is carving into a stone near the river. From the hands of the man the tender legs of the giraffe flow into stone. And you and the giraffe and the man and the stone breathe through one another. Through the ears of the giraffe you hear that the universe is inscribed in the body of the man, that the giraffe snorts from the stone, that you yourself gleam in geometric patterns across his hide. You sense that the man feels himself at one with the sky and the birds and the veld and the animals (2003, p. 137).

The sense of interconnectedness is so strong that man, animal and stone need the other to breathe. While the man is etching a picture of a giraffe into the rock, Krog's writing does not posit man as the subject creator and the etching as the product or object. Rather, subjectivity flows between man and animal as the 'you' hears and sees through the eyes and ears of the giraffe. Like Breytenbach's (1996, p. 89) contention that 'we are interchangeable with the land and vegetation and animals and spirits', the boundaries between the man, the 'you', the animals and the stone seem to dissolve in Krog's prose poem.

\section{Conclusion}


In a discussion of imperial landscape Mitchell (2002, p. 29) argues that 'contestation and struggle are inscribed indelibly on it'. Krog engages with the landscape that has long been at the centre of political and ideological struggles in her country. Mitchell (2002, p. 6) points to the following extract from Kenneth Clark's 1949 work Landscape into Art: 'We are surrounded with things which we have not made and which have a life and structure different from our own: trees, flowers, grasses, rivers, hills, clouds. For centuries they have inspired us with curiosity and awe. They have been objects of delight'. Mitchell (2002, p. 6) contends that "there is a "dark side of the landscape" and that this dark side is not merely mythic, not merely a feature of the regressive, instinctual drives associated with nonhuman "nature" but a moral, ideological, and political darkness that covers itself with precisely the sort of innocent idealism Clark expresses'. Krog's works reveal and critique the ways in which the land and landscape have been appropriated by both imperial and patriarchal discourses. Her interaction with the landscape is never as simple as merely viewing it as 'objects of delight'. Even as she challenge the utilisation of the landscape for purposes of disempowering women, she knows that 'they can never write the landscapes out of their system' and she thus attempts to foster a new relationship with the landscape that both acknowledges its complexities and ambiguities and recognises it as a constitutive part of her own body and identity.

\footnotetext{
Notes

${ }^{1}$ This quotation is taken from an essay by Breyten Breytenbach entitled 'The lines have fallen unto me in beautiful places (how to help a character out of a story)' (pp. 106-116) in his collection The Memory of Birds in Times of Revolution (1996). The essay contains an imaginary conversation between Breytenbach and a man who 'would present himself as Mr Lexie or $\mathrm{Mr}$ Eilex or Mr Ixele' (p. 106). This was a liminal character in Breytenbach's Return to Paradise who ended up being written out of the novel. However, Breytenbach found that he has been 'ill at ease ever since [this omission]' (p. 106) and that he was somehow 'still tied to [this character] by guilt'. The imaginary conversation that results from this guilt involves a discussion of white people's identity in Africa. Breytenbach's comment that, for white people, the 'continuous crystallization of identity had always been a local obsession' (p. 109) provokes the following response from Mr Ixele: 'And they can never write the landscapes out of their system. The natives hereabouts are not bothered by any sort of dichotomy between environment and man. Their trees and mountains speak with the voices of forebears. As for us [he leaned forward in a familiar fashion], can we say the lines have fallen unto us in beautiful places? Our initiation was a life-sickness. We had to go on writing ourselves out there to fit a tongue to the mouth. And then we lost the language. Are the lines not also nooses?' (p. 108) [emphasis in original].

${ }^{2}$ I use patriarchy in the broad sense of Sylvia Walby's (1990, p. 20) definition of the term as 'a system of social structures and practices in which men dominate, oppress and exploit women'.
} 


\begin{abstract}
${ }^{3}$ While there are other power relations that flow from, for example, Krog's upper class position and heterosexuality, this article focuses on those that result from her white female body in the South African context.

${ }^{4}$ I define misogyny as hostility towards or mistrust of women. It is a form of prejudice that manifests itself in a variety of concrete ways. I agree with Judith M. Bennett (1991, p. 183) that the original meaning of the term (a hatred of women) 'encourages us to underestimate both misogynists and their effects'. If one focuses only on individuals who express an explicit hatred of women, one loses sight of the extent to which misogyny is a pervasive ideological phenomenon that impacts the lives of all women through effects ranging from ridicule to female genital mutilation.

${ }^{5}$ Further works that have been useful in understanding the distinction between land and landscape are A Feminist Glossary of Human Geography (1999), The Anthropology of Landscape: Perspectives on Place and Space (1995), Sensuous Geographies: Body, Sense and Place (1994), Approaches to Landscape (1999), Undomesticated Ground: Recasting Nature as Feminist Space (2000) and Writing Worlds: Discourse, Text and Metaphor in the Representation of Landscape
\end{abstract} (1992).

${ }^{6}$ The equation of women's bodies and the land is not an exclusively African phenomenon. On the contrary, in her analysis of the discursive practices of the European settlers of North America, Annette Kolodny $(1975$, p. 4) argues that the metaphor of 'the land as woman' is probably America's oldest and most cherished fantasy'.

${ }^{7}$ In her analysis of the intersections of identity, gender and landscape in Ireland, Catherine Nash (1993, p. 40) confronts similar theoretical challenges when she explores 'the possibility of a feminist and postcolonial identification with place which avoids the biologism and essentialism of the idea of a natural, organic and intuitive closeness to nature in the former and a native, childlike and racial closeness to nature in the latter'. Gillian Rose (1993, p. 74) also explores the implications of associating women with nature in the nature/culture binary.

${ }^{8}$ In the "Summer" section of "Four Seasonal Observations of Table Mountain", Krog hints at the futility of any attempt to deny the landscape: "because the more she's abused for loot/ or ideology,/ the more she moults and shakes herself clean" (2006:110-111). Like Table Mountain, the landscape will always be part of the human consciousness and will demand engagement. ${ }^{9}$ In her analysis of Tsitsi Dangarembga's Nervous Conditions (1988) Katrin Berndt (2005, p. 112) identifies the Zimbabwean landscape of Tambudzai's childhood as one of the layers in her identity palimpsest. According to Berndt, the 'countryside of Tambu's childhood, the river Nyamarira and her family's fields represent a safe place to the protagonist, probably the only space where she ever felt wholeness'. This connection does, however, remain a complex one that is riddled with contradictions. Even as Tambu 'yearns to overcome the limitations connected with her rural life', she finds that 'her attachment to the rural landscape remains persistent'. Crucially, Berndt (2005, p. 113) demonstrates how, '[a]s identity layer, the landscape is heavily connected with the body'. She explains the importance of this corporeal attachment to the landscape by contrasting Tambu's experiences with those of Nyasha: 'Nyasha lacks this energy source, she is alienated from her own body. Tambudzai experiences distance from her biological functions as well, for example at the onset of her menses [see Dangarembga, 1988, p. 95], but because she can remember the once-existing unison between body and mind, she manages to uphold this stabilizing identity layer'. She is able to draw on 'these "old places" [that] remain an inalienable part of her being' (Berndt, 2005, p. 113). According to Sugnet (1997, p. 41) these landscapes of her childhood are still 'available to Tambudzai as sources of strength and points of orientation'.

${ }^{10}$ Beningfield (2006, p. 4) makes important points about how 'the connection to the body in and within the land' functions in terms of black South African identity.

${ }^{11}$ All translations from Afrikaans to English in this article are my own.

${ }^{12}$ Krog repeatedly writes back to the imperial trope that conceptualised Africa as an empty continent awaiting colonial appropriation. Also see her 'leeg lê die binnekant van hierdie land' [empty lies the interior of this land] in Lady Anne (1989).

${ }^{13}$ Krog alternates between the first and the third person narrator throughout A Change of Tongue. Both types of narrators are closely identified with Krog the author.

${ }^{14}$ In A Change of Tongue the labour of the black man on the farm owned by the narrator's family is revealed in an interview she does with Sebata Isak Mokokoane, who 'had been the foreman on [their] farm all of his life' (2003, p. 29). Isak says: '[o]n the farm I looked after milking, sick calves, chickens, every year the coop was full of chicks that had to get ants fed to them, pruning trees, grapes, making drains and diggings, I slaughtered sheep, cattle, pigs, I built with sandstone, 
dolerite, brick, I put in ceilings, plank floors, gutters. I put on roofs. I drove cars, tractors, trucks. For years I drove you to school, fetched fodder for the farm' (30). By listing the things Isak did on the farm, Krog makes it clear that his labour was indispensable to the running of the farm. Isak wants '[j] ust a small bit' of land so that he can stay on the farm as all his 'efforts lie here'.

${ }^{15}$ Vlakplaas is a notorious site where opponents of the apartheid regime were taken and tortured or killed. Vlakplaas can directly be translated as 'shallow farm'.

${ }^{16}$ When black men and women do become visible in writing about land, their labour tends to be either undervalued or taken for granted. In The Conservationist, Nadine Gordimer (1975) dramatises the presence of the black man on the farm through the figure of the corpse of an unknown black man that literally rises from the soil of the farm owned by the white farmer Mehring. Joya Uraizee (2000, p. 41) analyses Gordimer's work in This is No Place for a Woman and notes that, ' $[\mathrm{b}]$ esides the men, there are the women who seem to be even deeper in the darkness. They are described as bits of humanity - bodies, arms and legs - who move like animals'. The invisibility of women on South African farms is addressed by the Women on Farms Project, which is an NGO based in Stellenbosch. They argue that the lives of women on farms 'have not altered since the inception of the new government in 1994' since South Africa's 'new gender sensitive laws' do not adequately consider the 'extent of their powerlessness due to their lives being dominated by a male partner and a farmer as well as the isolation from resources [...] As a result, women farm workers are made invisible.' (1998, p. 9). This NGO has recently received greater press coverage after it was 'discovered that some farmers had employed a private investigator' (2007, p. 5) to look into the NGO's activities. Fatima Shabodien from the Women on Farms Project has responded that 'the NGO was being targeted because of its "very visible work" in fighting for the rights of women farmworkers'. The report also noted that it was 'ironic that farmers complained that they were unable to pay workers R 48 a day, yet were able to fund a private investigation'. This amount, which farmers are unwilling to pay, would be a woman's remuneration for a full day of manual labour.

${ }^{17}$ This South African word originally referred to a formation of wagons in a circle that was used by travelers to protect cattle, horses and people from attacks.

${ }^{18}$ The stockpiling of canned goods and emergency provisions of bottled water and candles in anticipation of the first democratic election in 1994 was also a common occurrence amongst white people in towns and cities.

\section{References}

Abrams, Meyer H. (1999) A Glossary of Literary Terms. Seventh edition. New York: Harcourt Brace College Publishers.

Achebe, Chinua. (1958) Things Fall Apart. London: Heinemann.

Barnard, Rita. (2007) Apartheid and Beyond: South African Writers and the Politics of Place. Oxford: Oxford University Press.

Bender, Barbara. (1993) 'Introduction: Landscape - Meaning and Action' in Landscapes: Politics and Perspectives. Barbara Bender. (ed.) Providence: Berg Publishers. pp. 1-17.

Beningfield, Jennifer. (2006) The Frightened Land: Land, Landscape and Politics in South Africa in the Twentieth Century. Oxford: Routledge.

Bennett, Judith M. (1991) 'Misogyny, Popular Culture, and Women's Work' in History Workshop Journal 31(1). pp. 166-188.

Berndt, Katrin. (2005) Female Identity in Contemporary Zimbabwean Fiction. Bayreuth African Studies 73. Bayreuth: Pia Thielmann and Eckhard Breitinger. 
Bethlehem, Louise. (2006) Apartheid Literary Culture and its Aftermath. Pretoria: University of South Africa Press.

Boehmer, Elleke. (1992) 'Stories of Women and Mothers: Gender and Nationalism in the Early Fiction of Flora Nwapa' in Motherlands: Black Women's Writing from Africa, the Caribbean and South Asia. Susheila Nasta. (ed.) New Brunswick, NJ: Rutgers University Press. pp. 3-23.

Breytenbach, Breyten. (1996) The Memory of Birds in Times of Revolution. London: Faber and Faber.

Bunn, David. (1994) “'Our Wattled Cot”: Mercantile and Domestic Space in Thomas Pringle's African Landscapes' in Landscape and Power. Thomas J T Mitchell. (ed.) Chicago and London: The University of Chicago Press. pp. 127173.

Coetzee, J.M. (1974) Dusklands. Johannesburg: Raven Press; London: Secker and Warburg (1982).

(1988) White Writing: On the Culture of Letters in South Africa. New Haven and London: Yale University Press.

. (1992) Doubling the Point: Essays and Interviews. David Attwell. (ed.) London: Harvard University Press.

(1997) Boyhood: Scenes from Provincial Life. New York: Viking.

Cosgrove, Denis E. (1984) Social Formation and Symbolic Landscape. London: Croom Helm.

Dangarembga, Tsitsi. (1988) Nervous Conditions. London: The Women's Press Ltd.

Foster, Jeremy. (1998) 'John Buchan's "Hesperides": Landscape Rhetoric and the Aesthetics of Bodily Experience on the South African Highveld, 1901-1903' in Ecumene 5(3). pp. 323-347.

Gaylard, Gerald. (2005) After Colonialism: African Postmodernism and Magical Realism. Johannesburg: Wits University Press.

Gordimer, Nadine. (1975) The Conservationist. New York: Viking.

Howitt, Richard. (2000) 'Scale and the Other: Embodiment, Emplacement and Infinity.' Paper submitted to Geoforum, May 2000.

<http://www.es.mq.edu.au/ rhowitt/Other.htm> [accessed 22 March 2007].

Jaffer, Zubeida, and Karin Cronje. (2004) Cameras, Microphones and Pens: Covering South Africa. Cape Town: Institute for Justice and Reconciliation. 
Kolodny, Annette. (1975) The Lay of the Land: Metaphor as Experience and History in American Life and Letters. Chapel Hill: The University of North Carolina Press.

Krog, Antjie. (1989) Lady Anne. Bramley: Taurus. (1998) Country of My Skull. London: Jonathan Cape. (2003) A Change of Tongue. Johannesburg: Random House. . (2006) Body Bereft. Roggebaai: Umuzi.

Loflin, Christine. (1998) African Horizons: The Landscapes of African Fiction. Westport, Connecticut and London: Greenwood Press.

Mitchell, Thomas W J. (2002) 'Imperial Landscape' in Landscape and Power. Thomas W J Mitchell. (ed.) Chicago and London: The University of Chicago Press. pp. 1-34.

Morphy, Howard. (1993) 'Colonialism, History and the Construction of Place: The Politics of Landscape in Northern Australia' in Landscape: Politics and Perspectives. Barbara Bender. (ed.) Providence: Berg Publishers. pp. 205-244.

Nash, Catherine. (1993) 'Remapping the Body/Land: New Cartographies of Identity, Gender, and Landscape in Ireland' in Feminist Review 44. pp. 39-57.

Nash, Catherine. (1994) 'Remapping the Body/Land: New Cartographies of Identity, Gender, and Landscape in Ireland' in Writing Women and Space: Colonial and Postcolonial Geographies. Alison Blunt, and Gillian Rose. (eds.) New York/ London: The Guilford Press. pp. 227-250.

Pratt, Mary Louise. (1992) Imperial Eyes: Travel Writing and Transculturation. London: Routledge.

Rose, Deborah. (1999) 'Indigenous Ecologies and an Ethic of Connection' in Global Ethics and Environment. Nicholas Low. (ed.) London: Routledge. pp. 175-187.

Rose, Gillian. (1993) Feminism and Geography: The Limits of Geographical Knowledge. Cambridge: Polity Press.

Said, Edward. (1978) Orientalism. London: Routledge.

Schaffer, Kay. (1987) 'Landscape Representation and Australian National Identity' in Australian Journal of Cultural Studies 4(2). pp. 47-60. < http://info.ccs.curtin.edu.au/AJCS_journal/J4V2/J4V2Landscape\%20Represent ation\%20and\%20Australian\%20National\%20Identity.htm> [accessed 22 March 2007]. 
Schama, Simon. (1995) Landscape and Memory. London: Harper Collins Publishers.

Spearey, Susan. (2000) 'Displacement, Dispossession and Conciliation: The Politics and Poetics of Homecoming in Antjie Krog's "Country of my Skull"' in Scrutiny2 5(1). pp. 64-77.

<http://www.uwc.ac.za/arts/english/LAMP/spearey.html > [accessed 28 March 2007].

Spivak, Gayatri Chakravorty. (2003) Death of a Discipline. New York: University of Columbia Press.

Sugnet, Charles. (1997) "Nervous Conditions”: Dangarembga's Feminist Reinvention of Fanon' in The Politics of (M)Othering: Womanhood, Identity, and Resistance in African Literature. Obioma Nnaemeka. (ed.) London: Routledge Press. pp. 33-49.

Suleri, Sara. (1992) The Rhetoric of English India. Chicago and London: The University of Chicago Press.

Uraizee, Joya. (2000) This is No Place for a Woman: Nadine Gordimer, Nayantara Sahgal, Buchi Emecheta and the Politics of Gender. Trenton, NJ. and Asmara, Eritrea: Africa World Press, Inc.

Viljoen, Louise. (2000) 'On Space and Identity in Antjie Krog's "Country of my Skull" (1998)'

$<$ http://academic.sun.ac.za/afrndl/personeel/Publikasiespersoneel/viljoen/Space\& Identity.pdf $>$ [accessed 2 April 2007].

Walby, Sylvia. (1990) Theorizing Patriarchy. Oxford: Blackwell.

Wenzel, Jennifer. (2000) 'The Pastoral Promise and the Political Imperative: The "Plaasroman" Tradition in an Era of Land Reform' in Modern Fiction Studies 46(1). pp. 90-113.

Women on Farms Project: Submission on Domestic Violence, Access to Justice, Maintenance. On 'Women's Net' <http://womensnet.org.za/pvaw/laws/farms.htm> [accessed 9 April 2007]. 
Correspondence: Jessica Murray, Centre for Culture and Languages in Africa, University of Johannesburg, P.O. Box 524, Auckland Park, Johannesburg, 2006, South Africa, Email: jmurray@uj.ac.za 